
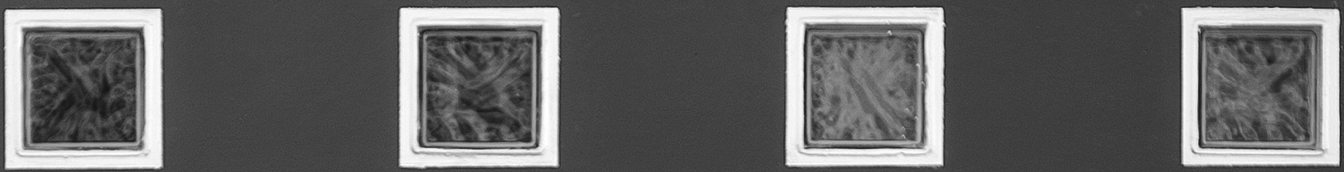

AIBR

Revista de Antropología Iberoamericana

www.aibr.org

Volume 12

Number 1

January - April 2017

Pp. 31 - 52

Madrid: Antropólogos

Iberoamericanos en Red.

ISSN: 1695-9752

E-ISSN: 1578-9705

\title{
(Forced) Sterilization in Peru: Power and narrative configurations
}

Ainhoa Molina Serra

Universidad Autónoma de Barcelona (España)

Received: August 8, 2016

Accepted: January 24, 2017

Dol: 10.11156/aibr.120103e
Translation:

Ashley Woodward

(The State University of New York at Potsdam)
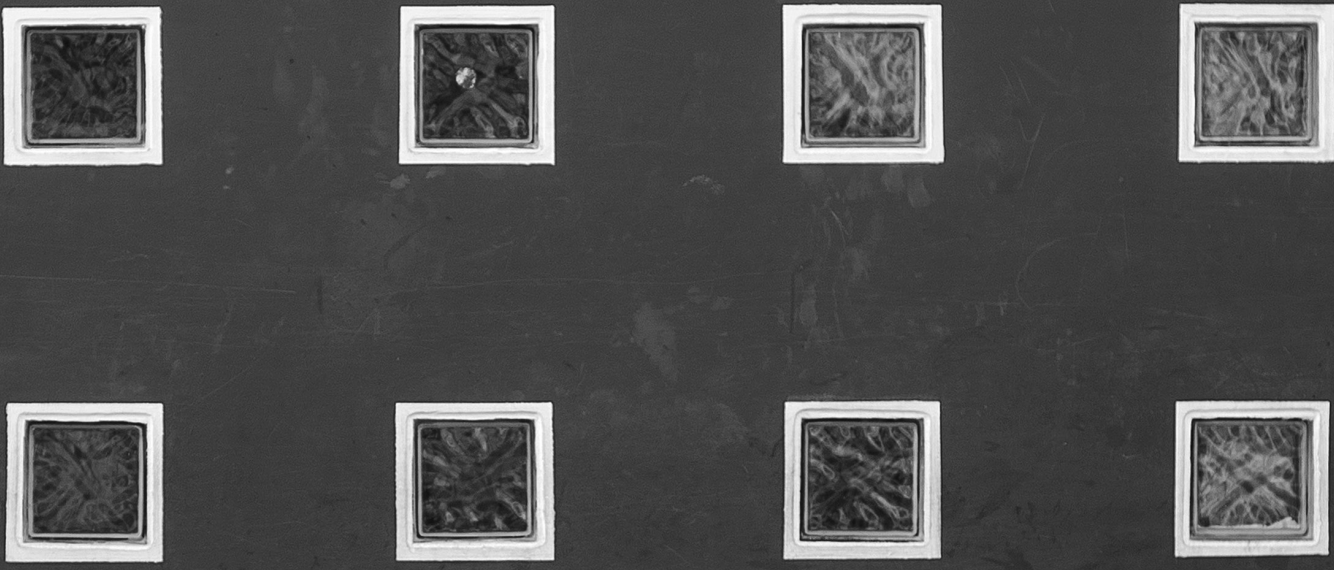


\section{ABSTRACT}

In Peru, between 1996 and 2000, the government of former President Alberto Fujimori implemented a family planning policy that resulted in the sterilization of approximately 300,000 people. Since then, the presence of this issue in the public sphere has led to the development of different opinions among several groups of the Peruvian society. The narratives that have been established as dominant discourses speak about forced sterilizations and victims, while Fujimori's government officials deny the existence of illegal violating practices. In addition, there are other minority narratives that are being ignored by their little relevance to the political debate, whose perspectives complement the reflections on this subject. This article examines the approach of both the current dominant public discourses and those lesser-known narratives; providing a critical look at the victim-centric approaches.

\section{KEY WORDS}

Peru, sterilizations, discourse, power, rights 
«It is impossible to find a memory, a unique version and interpretation of the past, shared by all the society (...) There will always be other stories, other memories and alternative interpretations (...) The space for the memory is a space of political struggle». (Jelin, E., 2002: 5,6)

\section{Introduction}

The sterilization of thousands of people during the second term of ex-president Alberto Fujimori —now imprisoned for crimes against humanity ${ }^{1}$ caused a landslide of accusations that showed the illegal practices during the execution of his birth control program. The race of numerous reports and the consequences of the candidacy of Fujimori's daughter Keiko in the presidential elections of 2011 and 2016, the issue has been very present in the political debates of recent years, since it has served the opposition parties to the candidate to the fuijimorista heiress.

This political debate that gave rise to the elaboration of different narratives by various groups of Peruvian society. The current discourses from the greater media coverage, which end up being reproduced in many daily conversations, call the family planning policy a policy of «forced sterilization». They are two words that are regularly united, punctually speaking about massive sterilizations and, rarely, simply sterilizations, without adjectives. The label frames the discourse in the violation of human rights and contributes to generate public debates that start from a legitimized humanitarian approach to portray the people affected by this policy as victims of the abuses of state power. They are speeches whose media presence affirm them as dominant and - although the existence of forced sterilizations is undeniable- leaves little room for a critical and broader reflection on this subject.

The central idea that questions this article is that the dominant discourses focus their efforts on a single objective: to identify the victims, to denounce their pain and demand justice. In my opinion, this desire to fight for the rights of the victims - however dignified and necessary it may be in a highly hierarchical society such as the Peruvian one- entails two risks: consensual stereotyping of indigenous populations as passive subjects and restraining the history of sterilizations to the scope of the human rights approach, whose limited analysis limits the understanding of the

1. In order not to confuse the reader, it should be mentioned that the crimes for which A. Fujimori was sentenced to custodial sentences are not related to the policy of sterilization, but to other crimes committed during his term as crimes of homicide and corruption. 
experience in all its complexity. This hampers a broader and enriching reflection on this topic that covers other aspects beyond the humanitarian and supportive view of power groups. Therefore, it is suggested the need to extend the sterilization study to the life histories of the affected women and their families to avoid limiting it to the specific event. For this, in addition to the documentary analysis, we have worked from an ethnographic approach with families that are recipients of this policy, with health personnel and NGO workers².

\section{Politics, justice, and language. Dominant representations about the sterilization experience.}

"The grand number of forced steralizations that took place in Peru in the 90's has left a wave of suffering that can only begin to be remedied if its victims have access to justice and reparations», explained Erika GuevaraRosas, director of Amnesty International (Diario La República, 22.10.2015). Justice for women victims of forced sterilization was one of the promises of Ollanta Humala during the electoral campaign of 2011, but the creation of a Registry of Victims has been waiting until its legislatura is almost finished: "End the long wait, start the time of justice» sentenced Nadine Heredia, wife of a Peruvian politican (Diario La República, 6.11.2015).

Victims, suffering and justice are the main words that currently make up the narratives with the greatest media coverage and through which the hegemonic discourses have settled. This humanitarian approach finds its origin in some investigations and denunciations that accused to the fujimorista government to develop a state policy whose immediate objective was to diminish the high indices of poverty of the country limiting the birth control of the poorest people (Comité de América Latina y el Caribe para la defensa de los derechos de la mujer, 1999; Congreso de la República del Perú, 2002; Defensoría del Pueblo del Perú, 1998 y 1999).

When Fujimori assumed the presidency in 1990, he found a country in bankruptcy, with an inflation of $7.650 \%$ (Marcus-Delgado, J., and Tanaka, M., 2001: 58). To revive it, it imposed severe measures of economic adjustment that would reinsert Peru in international financial circles. As part of its strategies to reduce poverty, Fujimori opted to reduce the births of the poorest families and launched the National Population Program 1991-1995, with which it was proposed to increase the use of contracep-

2. Press reports and testimonies obtained during the fieldwork conducted in Peru between 2013 and 2015 have been analyzed. 
tive methods. However, although fertility had declined in recent years, it was still very high in rural areas, and in 1996 the Reproductive Health and Family Planning Program 1996-2000 was launched, which included a method called Voluntary Surgical Contraception which, in practice, consisted in the sterilization - not always voluntary- of approximately 300,000 people, of whom about 250,000 were presumed to be women.

Likewise, it has been shown that this policy was implemented through illegalities and abuses towards health personnel and the target population -mostly indigenous women with low economic resources-. Among these irregularities, the following conditions have been denounced: the pressure received by medical personnel to meet the numerical quotas imposed by the Ministry of Health in exchange for keeping their jobs; the deceptions and bribes with which some patients were convinced to operate; the precariousness of the operating rooms where the surgeries were improvised, and the massiveness with which the surgical interventions were carried out, since some testimonies refer 60 operations in a day (Ballón, A., 2014, Ewig, C., 2010, Lerner, A., 2009)

To date, more than two thousand complaints have been filed with the National Prosecutor's Office and several legal proceedings have been initiated against Fujimori and other members of his government; however, the cases have been closed $^{3}$ because of lack of criminal liability. Nevertheless, activists and NGOs persist in the struggle for justice and their pressures led the government of Ollanta Humala to create, in December 2015, a Registry of Forced Sterilization Victims "whose purpose is to promote access to justice (... ) for the forced sterilizations victims during the period 1995-2001» (Resolución Ministerial nº 0319-2015-JUS).

The epicenter of the dominant discourses - very present in the public sphere through the press- is in the pain of the victims and that is where transitional justice ${ }^{4}$ focuses its eyes; in the objective damage that has been done to innocent beings, posing a reparation in response to their demands (Mate, R., and Mardones, JM, 2003: 100-103). "We demand justice and reparation. Of society, without the possibility of working or receiving medical attention ever since», said Esperanza Huayama, a victim of forced sterilization (BBC Mundo, 9.11.2015). Justice would lose its point of departure if the victims did not suffer; it is his affliction that refers to injustice and, consequently, to the demand for compensation to mitigate his suffering. Then, if pain is at the center of the question, how can these

3. The case was last filed on December 7, 2016.

4. Transitional justice is the set of judicial and political measures that are carried out in times of transition after a state of conflict or repression by a state, to repair mass violations of human rights. 
images represent the image of the victims and their suffering? For this, Madrid warns us of the need to know the context in which the concrete experiences of pain have taken place and to analyze the social practices in which the suffering is immersed (Madrid, A., 2010: 41).

Contextually, the suffering of these victims has a long history, previous to the antinatalist policy. The indigenous population in Peru has historically been marginalized by the State because it is the poorest and far from institutions and centers of power; something that was reflected in the scene of more recent armed violence ${ }^{5}$, where it was the most harmed both by the aggressions of the State and the terrorist groups. During the armed conflict, the intensity of violence was not uniformly distributed throughout the national territory, but concentrated mainly in the poorest departments of the country. The majority of the victims were peasants with low economic resources. In addition, the CVR highlights «gender violence» during the war, since a large number of victims were sexually abused for the sole purpose of being women (CVR, 2003: volume VI, page 276). In this context, and taking up population policies, the current majoritarian discourses attempt to denounce and make visible, once again, the suffering of the historically most vulnerable population of Peru.

Whatever its cause, suffering is built relationally and forms part of the power relations (Madrid, A., 2010; Le Breton, 1999). Thus, the experience of pain and its narrative constructions are associated with the relationships that people maintain with each other, and it is in the functioning of these relationships where the domination of the one who exercises the power over the one who suffers it is shown; it is this abuse of authority that provokes outrage and mobilizes the social agents with the capacity to claim justice to activate their mechanisms of protest.

Struggles for justice are generally not silent, but produce greater effects the more publicly their demands are made and shared and backed by a greater number of agents who have the capacity to exert pressure on the oppressors. It is in this context of power, relations, and legal battles that the narratives of suffering emerge that, for their legitimate purpose, are presumed authorized to construct representations about «the Others» through classifications and categories that shape the discourses. These constructions are articulated through words, for «suffering is an experience surrounded by language» (Madrid, A., 2010: 18) and this introduces concepts through 
which we identify ourselves and/or identify others, while determining the way in which the relationships between them are articulated.

But who are the institutions or the people whose words create public opinion, the valid speech? They are, in Van Dijk's words, the «symbolic elites»: NGOs, the Ombudsman's Office, political parties, the Catholic Church, social academics and the media (Van Dijk, T. A., 2007: 18). Actors who struggle for power, legitimizing their narratives to establish and elaborate the «official history / memory» (Jelin, E., 2002: 39). In them lies the power to make public the suffering of the victims and to handle the language with which to represent their misery: "A large part of the women affected are indigenous and peasants with low resources and Quechua speakers whose health was affected and deteriorated as a result of the surgical procedures to which they were subjected without being properly informed», said the executive director of Amnesty International in Peru, Marina Navarro (Diario La República, 22.10.2015); «Forcible sterilizations are an attempt on life»-Monsignor Oscar Alzamora reported (Diario La República, 15.05.1999)—, in the PNSRPF Archive); "Women are unaware of their civil and moral rights, and to date they do not understand what they did to their bodies. They do not know what this operation called Voluntary Surgical Contraception (AQV)» consisted of — social activist and feminist activist A. Ballón (2014: 35)—.

The public history of sterilizations is woven through phrases and meanings with which official discourses are drawn, which attribute definitions and concepts of «ones» about «others», ideas and evaluations that determine not only the official history but also, the identity of each subject in the frame of that memory. We hear of «indigenous/peasant/low-income women» whose circumstances call the listener's compassion because: «their health was affected and deteriorated / they were subjected without proper information / there was an attack on life» and also because they are presumed ignorant - a word that is avoided being used publicly but is understood- because "they are Quechua speakers, they do not know their civil and moral rights, to date they do not understand what they did to their bodies, they do not know what the operation consisted of». These are maxims that emanate from academic people, are learned and then inhabit the Lima society. As Pierre Bourdieu says «the power of words is not in the words themselves, but in the authority they represent and in the processes linked to the institutions that legitimize them» (Jelin, E., 2002: 35 ). Thus, when the speaker speaks from a privileged social position, his words become singular truths that make up the authentic narration «of 
what happened». And this «what happened» from the hand of power, becomes the official discourse.

As we know, language is not socially neutral, since the most important concepts and categories of language are modeled by society (Abercrombie, N., 1982) and «it is in language how the world is given meaning, things are classified...), thought is formed and concepts are formed about reality, also about suffering... If we take one more step, we can see that these languages are created and sustained institutionally and have effects in certain contexts» (Madrid, A., 2010: 25).

This language, no doubt well-intentioned, has no other primary purpose than to obviate an unjust situation, a worthy task championed by NGOs and supported by other groups of social activism. Is there anything that can be blamed for this? Apparently not. We need institutions that work for human rights and, in case of injustice, denounce it by words; and not by any kind of words, but those that shake the conscience of the people and shame those responsible. However, the excessive use of this language carries the risk of transmitting messages that — probably unintentionally by the speaker- fuel stereotypes that contribute to create the same hierarchies and inequalities that these groups seek to address. The danger of legitimizing and making official the speeches that portray women sterilized as "poor indigenous people who do not know their rights and do not know what they did to their bodies» is that almost inevitably promotes in the collective imagination the idea that they are ignorant people who can be easily abused, as one health technician put it to interview: "It's difficult to convince people here in the city, but the people from the country can be easily convinced, you can manipulate them very easily». ${ }^{6}$

The threat of these stereotypes is that they reinforce the paternalism of power groups, who in their commendable mission to defend the rights of the victims are assigned the - probably unconscious- faculty of attributing to them; an identity of dependence and subordination. Ultimately, most of these dominant victim centric discourses carry good intentions, seek to exhibit an injustice, and are much needed in contexts of inequality, but that merit does not release them from the threats of collective prejudice. Their statements, while at the same time sympathizing with the most disadvantaged, create the same hierarchies that normalize the power relations that have provoked the abuses that they strive to denounce.

In addition to "officially» specifying the victims" description and the state of their suffering, the dominant public narratives extend to the recent political debate, where the daughter of the former president Fujimori has

6. Interview with a health technician in Huamanga (Ayacucho), 04.30.2015 
fought to win the $2016^{7}$ elections, the issue of sterilizations would rob her of the presidency, as it did in the previous legislature against Ollanta Humala. The lawsuit against her father has been repeatedly filed and judicial decisions that have argued that he has not found enough evidence to blame the former president and his collaborators that have sparked widespread criticism of Peru's poor functioning and alleged corruption. The case does not conclude, or at least, does not conclude with justice for the victims, a circumstance that maintains it in force in the political sphere, stimulating heated debates between the Fujimorismo and the opposition parties during the electoral campaigns.

From political parties and other groups opposed to Fujimorismo, the responsibility of the former government is argued: «Forced sterilizations were state politics», says Miguel Palacios, Dean of the Medical College of Peru (Diario La República, 25.04.2016) and the former First Lady mourns the last file of the criminal case glorifying the merit of her husband's former government: "Nadine: Surprised that prosecution file case of sterilizations. Nadine Heredia recalled that the nationalist government implemented the registration of victims of forced sterilization» (Diario El Comercio, 02.08.2016). On the contrary —and in reply to the above- the Fujimoristas defend themselves by denying the existence of a massive population control policy: «Fujimori denied that they were 300,000 victims and pointed out that there were 'some denunciations', of which only materialized 30 in the Office of the Prosecutor", argued the presidential candidate of Popular Force, Keiko Fujimori (Diario La República, 08.03.2016) and the press establishes the state of the discussion in the struggles for power between the political subjects: «Peru looking towards the ballot: the forced sterilization of politics» (Canal Telesur, 04/21/2016).

Likewise, within the political ring, a space is opened for the performance of justice, where there is a legal jargon technique that exposes the subject of forced sterilizations through a juridical-procedural vocabulary that places its public debate within the sphere of the performance of the law. Here we come across the messages derived from the political-juridical discourse: "The Inter-American Court of Human Rights in 2010 reminded the Peruvian State of the commitment it signed in 2003 to 'properly investigate and punish those responsible', and for this reason, 2011 the reopening of the case» (Diario El País, 24.01.2014); "Victims of the forced sterilizations of Cusco and Piura filed an appeal yesterday to the Second Supraprovincial Prosecutor's Office against their resolution that files the investigation that followed former President Alberto Fujimori and his

7. Keiki Fujimori lost the elections with $49.72 \%$ of the votes as opposed to Pedro Pablo Kuczynski, who won with a small margin earning $50.28 \%$ of the votes. 
former health ministers for the alleged crime against humanity» (Diario El Comercio, January 29, 2014.)

We are faced with a political scene and judicial proceedings whose languages invite us to construct narratives that no longer focus mainly on describing victims and blaming their suffering situation, but alternating between political controversy and the procedural status of the criminal case .

\section{The Speeches of the Victims: Recognition and Power}

The term «victim» has been used since olden time, however, «there is no single concept, but its definition will depend on the field or legal or social branch in which it intends to develop» (Morillas Fernández, DL, Patró Hernández, RM And Aguilar Prisons, MM, 2011: 95, 102). In general, victims are spoken about in order to demand responsibilities, but also «to pose the actuality of their rights, denied in the past, to those who now recognize their validity» (Mate, R., and Mardones, JM, 2003: 100).

In Peru, twenty years after the events, neither responsibility nor recognition has arrived and ordinary justice has not yet foreseen concrete forms of reparation. This would require the Justice Administration to publicly admit the crimes committed and condemn them, as well as to confirm the triumph of the victims and to undertake a state work of recognition in favor of the victims as persons of law. Recognition is a fundamental aspect of social struggles (Honneth, A., 1997). At the same time, it constitutes a determining factor in the construction of identity, since it's set up collectively in dialogues with others and is modeled, in part, both for recognition and for lack of it (Taylor, Ch., 1993).

Here we speak of victims, to refer to people sterilized against their will. Men, but above all, women to whom health services imposed tubal ligation and vasectomy as the only free methods of contraception. They also elaborate narratives; the difference with the other discourses is that these are generated from testimonies in the first person: "They did not explain, they took me just, very many women were in the hospital, they locked the door and they did not let us out (...) We wanted to leave but really couldn't anymore, what we are going to do. We are from the countryside, we are innocent, we did not know how to explain ourselves, and they tied us" (Ballón, A., 2014: 151). They are memories that testify to the abuse of power, the same that justifies the struggles for the recognition of those who have suffered unjustly. In the course of that purpose, the disadvantaged learn the language and integrate its meaning: "We are from the countryside, we are innocent». Certainly, when we speak of victims, 
we are thinking of the harm done to innocent beings - those who have had no degree of participation in the wrongful act - (Morillas Fernández, DL, et al., 2011: 97), Being the innocence, "the state of who suffers an injustice without deserving it» (Mate, R., and Mardones, JM, 2003: 100).

«Innocent victims», «rural women», "pseople who did not know and they forced them", are categories that settle in discourses while being forged collectively in relationships with others, which are always relations of power where identities are defined. As Ricoeur puts it, the notion of identity is closely linked to the idea of power, while the answer to the question "who am I?" will depend on the answers we can give to «what can I do?» and "what can't I do? «(Ricoeur, P., 1998: 107) and this "being able to do" will be delimited by the recognition with which others give us.

In these battles for acknowledgement, a scenario of power games and identity configuration, there are people who, as Agüero has pointed out, seek to be victims and pursue the label that gives meaning and respect to their lives, because, «in countries such as ours [referring to Peru], where it costs so much to have a status of whatever, having the victim can be a step towards that of a citizen». In this sense, "victimization can be used as a political strategy to access justice and other scarce assets. Those affected by violations of human rights learn it and use it to their advantage" (Agüero, J.C., 2015: 106, 116). Thus, in a country where "women are more Indian» (De la Cadena, M., 1992) and whose power spaces are reduced, the demand for acknowledgement becomes urgent in a society where the indigenous population has been historically disrespected and more specifically, where indigenous women occupy the last link in the hierarchies of social inequality.

\section{Sterilization policy and «people of the field». Narratives from health personnel.}

The medical staff and health personnel were elementary participants in the implementation of family planning policy, as they were directly involved and asked to practice sterilizations in compliance with the orders imposed by the Ministry of Health. There were those who, under pressure from the government, were forced to recruit people —especially women- to be sterilized; We spoke mainly of the technical workers of health centers and health posts who had not insured their employment contracts, who were directly required to meet numerical quotas. Some say, that despite having had to meet these goals, they acted with care, talking to people and explaining the benefits of surgical contraception: "As they asked you for 
goals, what I was doing was trying to give as much counseling, then I would reach 70-80\% of my goals [...] I felt particularly at ease because I knew that I was taking the people I had informed and I had given adequate counseling to women who had many children and who no longer wanted to have more» (interview with a clinic nurse in Ayacucho, 14.04.2015).

Never the less, the experience of other workers was not so peaceful, they have been given a moral burden until now to tell their experiences from guilt and repentance: "It was conflicting for me to see myself involved in convincing a woman and more with the consequences we had... I feel bad... because I had to do it and that is something... not prescribed, shall we say? because it is a guilty conscience..." (interview with a nurse who worked in the health clinic in Ancash. Lima, 10.02.2015).

We observed that the experience of the technicians was different from that of the doctors, who were in charge of practicing the operations but did not directly suffer the pressure of the goals nor the risk of losing their jobs:

That was for women who had many children and did not want to have more, right? They came and we evaluated them, we asked; how many children do you have? If they had one or two we never let them be operated [...] maybe there were places where they have been deceived and forced, but we have talked to them, we have never done force nor have we ever thought that we are doing something wrong either, because actually family planning is needed right? Because with so many children they can not survive, they can not give them education, they can not feed them. (Interview with a doctor that worked in a hospital in the department of La Libertad. Lima, 13.02.2015)

Also here, the roles of power of the hierarchies come into play; while some technicians, pressed by government pressure, were forced to act against their will, some doctors feel they fulfilled the job well done, legitimizing their performance from the power of those who have the freedom to decide.

As we see, the experiences of health personnel vary according to their professional categories and their moral sense. But this is not all; The narratives continue beyond their consciousness. Their languages outlines a concrete image of the people to whom the policy was addressed, referring to patients as "country people», showing a remarkable intellectual, economic and socio-cultural distance between health professionals - who possess higher education and a certain intellectual level- and people living in rural and marginal urban areas, who are often represented as naive: "I think it is because of their need... before this whole area was 
extreme poverty... people of the countryside is very easy to convince, that's why the age of terrorism begins in the field» (Interview with a technician from a clinic in Huamanga. Ayacucho, 30.04.2015).

They are narratives that vary according to the perception and morality of each one, but what they all attest are the abusive conditions under which the family planning program was imposed: massive operations in improvised operating rooms, overcrowding of patients in hospitals, deceit and bribes through food or money to persuade patients to undergo surgery, etc., and most admit that these excesses were committed against the poorest and illiterate population because their ignorance made them targets of easy persuasive: "if they are humble people and at a low educational level they suddenly did not fully understand $100 \%$ of what they were really doing to them» (Interview with a doctor that worked in a hospital in the department of La Libertad. Lima, 13.02.2015).

In these discourses, again, language is important, for "there are no innocent words» (Bourdieu, P., 2008: 15). We hear of "people from the countryside / humble people / low educational level / did not understand / easy to convince», as equally significant to the social position of those who pronounce them. We are faced with power relations that denote a pronounced verticality between health agents and patients. This hierarchy has already been well researched by some social academics (Huayhua, M., 2006, Del Pino, P., Mena, M., Torrejón, S., Del Pino, E. Arones, M., and Portugal, T. They are speeches that do not speak properly of victims or of justice, but that, without looking for it, re-victimizes this "people of the field» that apparently lacks the minimum knowledge to be enforced in their rights. And again, even without pretending it, and however harmless the claims are intended to be, the inequalities are reproduced in the collective imagination of power groups, as indigenous people continue to be portrayed as vulnerable subjects to state power without any possibility to exercise their own agency ${ }^{8}$.

On the other hand, the majority of the workers in the health sector agree on the need to limit the births of the poorest populations in Peru, although they do not support the abusive forms used by the workers. They refer to the abundance of large families and the difficulties they face in

8. In this context I utilize the word «agencia» adopted from the English «agency», referring to the empowerment of women, or rather referring, to their actions, determination and position as decision makers. 
sustaining their children in areas far from urban centers where economic activity is precarious and access to public education is difficult to reach:

\begin{abstract}
Yes, you have to plan because having a baby means seeing your food, clothing, education and health, so if you are going to have a lot of children, can you give her a good dress? Can you give him good food, good education, good health? No, you will not! [...]But the way they have done the tubal ligation at the time, that should not have been so, right? Because that ligation has had to be informed and consented to and not be done by force (Interview with an obstetrician from a health post in a rural community in the Department of Ayacucho, 12.05.2015).
\end{abstract}

These are just a few examples of common narratives among health workers who, far from focusing on human rights discourse, accept the policy of sterilization as a necessary measure to reduce the birth rate of large families with insufficient economic resources. Unlike the speeches in the political scope, the arguments here do not go out of their way to uncover the victims and show their pain for justice, but rather, to accept the policy of sterilizations presenting a panorama of economic scarcity where the limitation of births is necessary in a country that offers no other measures for poverty reduction.

Also, apart from poverty as a main factor, there are also frequent arguments that appeal to the difficulty to educate the rural population about the use of other contraceptive methods, with sterilization being the best option in patriarchal contexts where men exert a machismo attitude which prevents women from deciding about their sexuality and their reproduction: "Well, it seems to me that they should be tied, because they have many children here, $6,7,8$ and sometimes women do not want to take care of their husbands... machismo still exists, doesn't it?" (Interview with a nurse from a health post in a rural community in the Department of Ayacucho, 08.04.2015).

There are also those who also justify sterilization because people in rural areas are seen as carefree people: "It was good for the countryside because they can not come to the hospital or go to their post and this was excellent... they stopped having many children, because as the women have so many chores in their farm they do not prioritize their health [...] for me I think the tubal ligation for the country people was excellent" (Interview with an obstetrics technician at a hospital in Huamanga, Ayacucho, 05/11/2015).

Most of these speeches are not part of the dominant debates on the policy of sterilization because they are not disseminated through the me- 
dia and have not acquired the scope of official speeches. However, this does not save them from transiting in the public space, circulating in the daily exchanges of people who talk and interact; As Ricoeur says "narration is first practiced in ordinary conversation in the context of reciprocal exchange» (Ricoeur, P., 1998: 20). And these are as responsible as the official discourses of legitimizing representations that define stereotypes and standardize hierarchies that normalize and justify relations of authority; elements by which the society of inequality is classified and organized.

\section{4. «Brave Women ${ }^{9}$ : other perspectives, other narratives.}

In this section I am interested in addressing some narratives of the sterilized women themselves and their families ${ }^{10}$. We have, on the one hand, those that are part of social movements, such as the Association of Women Affected by Sterilizations in the province of Anta (Cuzco department) led by parliamentary Hilaria Supa, whose testimonies support the narratives from the focus on human rights, dedicating efforts to obtain justice. Plus, on the other hand, there is the experience of the women - and their families - who are not part of any organization and who have not elaborated their discourse from the victims' point of view. These are the narratives that I want to explore here, because they are the least known and whose perspectives can contribute to generate novel reflections on this subject. Their explanations are broader, because addressing the experience of sterilization does not stop at the idea of justice, but embrace different spaces concerning family, relationships, economy, poverty, the era of armed violence, migration, future expectations for children, etc. They are stories that do not end in the discussion on human rights; but instead, they comprehend a broader and more comprehensive view, widening the space for reflections that extract the debate from the dominant approach.

Although the fact that the family planning policy of the Fujimori government was filled with abuse and irregularities, nor that many people were sterilized without their consent is not in question, it is not less true that not all persons who were sterilized did so. Not everything can be explained using the discourse of the innocent victim and the perpetrator. As Jelin points out, "maintaining the victim's centrality in discourses as a helpless subject, devoid of ability to act, carries the risk that it does not matter what the person did, but only what was done to him. This takes

9. Quote from an interview with a sterilized woman in a rural community in Ayacucho, May 2013.

10. Narratives derived from fieldwork conducted in Ayacucho, between 2013 and 2015. 
away the actor and gives us a defenseless, depoliticized character», evading his active involvement in history (Agüero, J.C., 2015: 98, 101). If instead of privileging the suffering of the victim in the narratives we emphasize other dimensions of the same story, we will know other senses of that experience that complement and enrich it.

These other relegated narratives come from subaltern voices, those that are not part of the official discourses and have been little or nothing examined by researchers and social scientists. These are the perspectives on sterilization told by women —and their families — who, unlike the dominant discourses, explain their experience as an opportunity to not have more children in a context of low economic resources where education is a priority that demands many sacrifices; and in patriarchal relations where women take care of the family and the home, the men are seeking to take control over reproduction: "the woman has to serve, she has to cook, the male does not help you [...] machismo is [...] working I have to serve the male, working you carry your son, that's why I had myself tied, five little children is already a lot» (Interview with a sterilized woman in Humanaga, Ayacucho, 10.03.2015).

Conflicts in the relationships of couples derived from alcoholism, infidelity and mistreatment is another reason justifying sterilization: "for my despair that I lived with a drunk and I could not bring more children to the world, that's why I called [...] otherwise, how many children would he have had? I would not even have been able to educate... if with two I almost can not... imagine!... no... I could not have...» (Interviewed a sterilized woman in Huamanga, Ayacucho, 02.03.2015); "He wanted to have many children, more and more children, but he hit me, mami ... he hit me hard... for 8 years he had been hitting me [...] there then on the post was a nurse who was my friend... she told me: "Why are you going to have more children? This man beats you; Get a ligation, it's just a touch no more [right away] and you will heal quickly' and that's why I did it, mami» (Interview with a sterilized woman in Huamanga, Ayacucho, 12.05.2014).

In this context of complicated relationships and economic difficulties, where free contraception was offered, there were couples who agreed on the decision to sterilize, but there were also women who decided to do so unilaterally, without the approval of their husbands. Women who took advantage of the absences of their husbands and who relied on other women to perform the intervention: "Well! Are the women we suffer to care for the children, with so many children it is difficult to buy clothes and everything they need, so only among women we agreed to make us tied together [...] If I had not done, I would have had 2 or 3 children more... that's what happened to the women who did not do it [the liga- 
ture]» (Interview with a sterilized woman in the rural community of Vilcashuamán, May 2013).

This initiative confronted some couples while challenging men's power roles, positioning women as the masters of decisions about their bodies and their reproduction. Alcalde defines these situations as «strategies that women have to resist the attempts of men to control their bodies" (Mayor, MC, 2014: 126), for there "where there is power, there is resistance" (Foucault, M., 1988:6).

Suffering is a common word in the stories of these women. They suffer to support their children, suffer for work, suffer to care for the home, suffer because they are mistreated, suffer because they have lost their relatives in the war. But unlike the speeches of the "symbolic elites" it is not the suffering of the helpless victims that needs to be denounced; it is the suffering resulting from the fatigue of a difficult life in all its context where it costs a lot of work to support a family and where education becomes a promise of progress and another reason for not having so many children. In a context where mothers and fathers have not been able to finish their studies, their children study becomes a hope for economic prosperity, and their efforts to pursue that goal are admirable.

Another issue directly linked to the sterilization that appears (and also disappears) in many of the conversations are the effects that the tubal ligation operation has on health. Women who associate sterilization with discomfort in the womb, weight gain or loss, body pain, weakness and changes in character as well as sexuality are recurrent. There are arguments that are changing and narrated with different emphases according to the moment of the conversation; arguments that are in the discourses but that the ethnography records of another way. All are women who work from early hours of the morning, carry heavy weight on their backs and walk long journeys. None of them has been impeded to work as a result of sterilization; on the contrary, their income is often the main basis of family support and most alternate jobs. However, this does not deny that there are women who, as a result of the sterilization, have been harmed by their work activity and therefore, their economy, as other research has pointed out (Ballón, A., 2014: 41-42).

In collation of the conversations about health, the stigmas and prejudices regarding the use of contraceptives appear. The consumption of pills, injectables or intrauterine devices causes side effects in the body that women associate with dizziness, bleeding, moodiness, headache, cancer and insanity. In addition, there is a belief that women who "take care» ${ }^{11}$

11. The word is used «take care», To refer to the taking of contraceptive methods. 
having a husband, do so in order to be unfaithful without incurring the risk of becoming pregnant. This circumstance threatens the male power of their partners, who "need to exercise control over the sexuality and reproductive capacity of women as they conceive them as part of their 'territoriality', with the risk of becoming pregnant what constitutes, for men, a fidelity insurance» (Yon, 1996: 76-77). All this together with a stigmatizing vocabulary that turns infertile women into "caponas», «anuladas», «amaradas», «machonas», «manavaleg» ${ }^{12}$, etc., Makes sexuality and contraceptives very interesting topics to be explored in relation to the study of family planning policies.

These are some brief examples of issues that place us in the complexity of the lives that these families are going through and that contradict, in part, at the same time that they complement the official discourses. In opposition to the victimized looks that stagnate the women under their suffering, here we can also notice the active agency of these families in the decision to control their reproduction. Their looks take us away from the dominant focus to give us the opportunity to investigate how that decision was made, understanding the causes that motivated it and its consequences. They also invite us to explore the effects on the body, health and to question its symbolic structure (Le Breton, D., 1999; Morris, DB, 1993) as well as the functioning of relationships, gender roles in the family, and the configuration of power relations. His accounts show us the limitations of addressing the history of sterilizations by talking only about others and the need to talk to others, whose experiences are far more complex and broad than the small scope to which we subject them.

\section{Conclusions}

All narrative construction stems from a subjective way of conceiving the world. In the case of sterilizations in Peru, some of these narratives are based on autobiographical experiences, and others are constructed based on the valuations of the experiences of others under their own criteria. All are valid in their own context while they all have limits. It is not a matter of endorsing and denying others, but rather of the selection and emphasis on certain dimensions or aspects of the past that different actors recover and favor (Jelin, E., 2002: 69). While the experiences, intentionality and

12. «Caponas» signifies a castrated animal; «Anuladas» refers to women having a void because they cannot accomplish their "mission» as a woman, which is to bear children; «Amarradas» refers to the women being «tied»; "Machonas» refers to the women who cannot have children because they lost the "female condition» of a woman; and «Manavaleg» signifies «worthless» in Quechua. 
expectations sought by social groups are different, the construction of the past will take the form of different interpretations, which will be modified over time in dialogue and negotiation with other agents.

For some, talking about sterilizations - in Peru- is necessarily talking about forced sterilizations and bring up a conversation about victims, suffering, justice and guilty. For others, the word "sterilizations» recalls feelings of guilt and repentance; and there are those who involve introducing reflections on social classes and authorized knowledge. For some sterilized women the adjective «forced» does not appear in the discourse and the emphasis is on talking about machismo, empowerment, and resistance, as well as money, family, work, education, future, illness, sexuality, and relief; while for other women the word «forced» is the one that gives them the recognition to be reaffirmed in their rights.

In short, the issues that can be addressed from that experience are immense; what changes are the agents and the approaches with which they elaborate their reflections, and depending on what experience we seek to understand, we will cover one or other point of view. They will all offer us one part of the story and deprive us of another. Then the discourses reach different spaces and their representations have a greater or lesser collective consensus, which places us in the position of power, where different groups struggle to impose theirs as dominant (Bourdieu, P., 2000: 20 ), when what is valuable, in fact, is to provoke dialogue between discourses that are not normally spoken.

Power, in the discourses, is concretized through language, institution (Searle, J.R., 1997) through which social groups struggle for the recognition of their representations of the past (Jelin, E., 2002: 36). Its legitimacy will be defined, in part, by the social position of the speaker, who will be the one who determines the access to the official word (Bourdieu, P., 2008) and which will be reinforced by the complicity granted by other groups, as the French sociologist says "the symbolic efficacy of words is not exercised to the extent that those who experience it recognize that the person who exercises it is authorized to exercise it" (Bourdieu, P., 2008: 69).

The warning that seems to me necessary to do is to warn about the risks of victimocentric discourses and to reproduce them as officers, since they include a lot of power and do not leave space for those other less official discourses but equally valuable that complement the dominant view integrating new contents to a subject as wide as this. By "officially» converting sterilized persons into victims, they tend to represent them almost without exception, as «non-actors», its said, as passive subjects who are impacted but who are not provoked nor respond (Jelin, E., 2002: 72). With this, I do not question that when we talk about this policy of 
sterilization we can talk about victims and not only direct victims of abusive politics, but also victims of a patriarchal system, hierarchical, and socially and economically discriminatory, both in the general politics field as in the more local context of their own families and communities. However, some of these narratives also allow us to polemize the ideas of victim and victimization by offering us elements to challenge the homogeneous images associated with sterilized women and to place this issue as a matter that engages the family and allows us to controvert power relations and the struggles for recognition in the gender relations that mark both the relationships of the couple and the relations of citizenship with the State. This implies that the victim ceases to be the center of the official discourse to give prominence to their motivations and wills, so that we can analyze their internal dynamics and «recover all those active agents in their complex humanity» (Agüero, 2015: 98).

\section{Bibliography}

Abercrombie, N., and Galmarini, M. A. (1982). Clase, estructura y conocimiento. Península. Agüero, J.C. (2015). Los rendidos. Sobre el don de perdonar. Lima: Instituto de Estudios Peruanos.

Alcalde, M.C. (2014). La mujer en la violencia. Pobreza, género y resistencia en el Perú. Lima: Instituto de Estudios Peruanos.

Ballón, A. (Comp.) (2014). Memorias del caso peruano de esterilización forzada. Lima: Biblioteca Nacional del Perú.

BBC Mundo (2015). Así fueron las esterilizaciones forzadas que ahora son asunto de interés nacional en Perú. 9 de noviembre de 2015.

Bourdieu, P. (2000). Poder, derecho y clases sociales. Desclée de Brouwer.

Bourdieu, P. (2008). ¿Qué significa hablar? Akal.

Canal Telesur (2016). Perú con miras al balotaje: la esterilización forzosa de la política. 21 de abril de 2016.

Comité de América Latina y el Caribe para la defensa de los derechos de la mujer (1999). Nada personal, reporte de derechos humanos sobre la aplicación de la anticoncepción quirúrgica en el Perú 1996-1998.

Comisión de la Verdad y Reconciliación de Perú. (2003). Informe final.

Congreso de la República del Perú. (2002). Informe final sobre la aplicación de la Anticoncepción Quirúrgica Voluntaria en los años 1990-2000. Lima.

Defensoría del Pueblo de Perú. (1998). Anticoncepción quirúrgica voluntaria I. Casos investigados por la Defensoría del Pueblo. Informe núm. 7. Lima.

Defensoría del Pueblo de Perú. (1999). La aplicación de la anticoncepción quirúrgica y los derechos reproductivos II. Casos investigados por la Defensoría del Pueblo. Informe núm. 27. Lima. 
Del Pino, P.; Mena, M.; Torrejón, S.; Del Pino, E.; Aronés, M., and Portugal, T. (2012). Repensar la desnutrición: infancia, alimentación y cultura en Ayacucho, Perú. Lima: Instituto de Estudios Peruanos-Acción Contra el Hambre, España.

De la Cadena, M. (1992). Las mujeres son más indias. Espejos y travesías, (16)

El Comercio (2014). Apelan el archivamiento de caso de esterilizaciones forzadas. 29 de enero de 2014.

El Comercio (2016). Nadine: Sorprende que fiscalía archive caso de esterilizaciones. 02 de agosto de 2016.

El País (2014). Perú cierra el caso de las esterilizaciones forzadas de Fujimori. 24 de enero de 2014.

El Peruano (2015). Resolución Ministerial nº 0319-2015-JUS. 4 de diciembre de 2015. Lima, Perú.

Ewig, C. (2010) [2012]. Neoliberalismo de la segunda ola: género, raza y reforma del sector salud en el Perú. (A. De la Cadena, Trad.). Lima: Instituto de Estudios Peruanos.

Foucault, M. (1988). El sujeto y el poder. Revista mexicana de sociología, 50(3):3-20.

Honneth, A. (1997). La lucha por el reconocimiento. Barcelona: Crítica.

Huayhua, M. (2006). Discriminación y exclusión: políticas públicas de salud y poblaciones indígenas. (No. E13 I5 No. 42-SSP). Lima: Instituto de Estudios Peruanos.

Jelin, E. (2002). Los trabajos de la memoria. Madrid: Siglo XXI.

La República (1999). 15 de mayo de 1999.

La República (2015a). Caso de esterilizaciones forzadas en Perú, el más grave de América Latina. 22 de octubre de 2015.

La República (2015b). Nadine Heredia sobre víctimas de esterilizaciones: «Empieza un tiempo de justicia». 6 de noviembre de 2015.

La República (2016a). Keiko Fujimori ofrece reparar a víctimas de esterilizaciones forzadas, «si hay alguna». 08 de marzo de 2016.

La República (2016b). Esterilizaciones forzadas fueron política de Estado. 25 de abril de 2016.

Le Betron, D. (1999). Antropología del dolor. Barcelona: Seix Barral.

Lerner, A. (2009). Las polémicas mediáticas en la campaña de esterilizaciones masivas en el Perú de Fujimori (1994-1998). BA dissertation. Pontificia Universidad Católica del Perú.

Madrid, A. (2010). La política y la justicia del sufrimiento. Minima Trotta.

Marcus-Delgado, J., and Tanaka, M. (2001). Lecciones del final del fujimorismo: la legitimidad presidencial y la acción política (Vol. 47). Instituto de Estudios peruanos.

Mate, R. and Mardones, J. M. (2003). La ética ante las víctimas. Barcelona: Anthropos.

Morillas Fernández, D. L.; Patró Hernández, R. M.; and Aguilar Cárceles, M. M. (2011). Victimología: un estudio sobre la víctima y los procesos de victimización. Dykinson.

Morris, D. B. (1993). La cultura del dolor. Andrés Bello.

Ricoeur, P. (1998). La lectura del tiempo pasado: memoria y olvido. Madrid: Arrecife.

Searle, J. R. (1997). La construcción de la realidad social. Paidós.

Taylor, Ch. (1993). El multiculturalismo y la política del reconocimiento. México: Fondo.

Van Dijk, T. A. (2007). Racismo y discurso en América Latina. Gedisa. 
Yon, C. (1996). Placer, riesgo y poder. Corresponsabilidad y negociación de hombres y mujeres respecto al uso de métodos anticonceptivos. En Coredero, M.; Jimenez, O.; Menéndez, M.; Valverde, R. y Yon, C., Más allá de la Intimidad. Cinco estudios en sexualidad. Salud sexual y reproductiva. Lima: PUCP, pp. 53-88. 